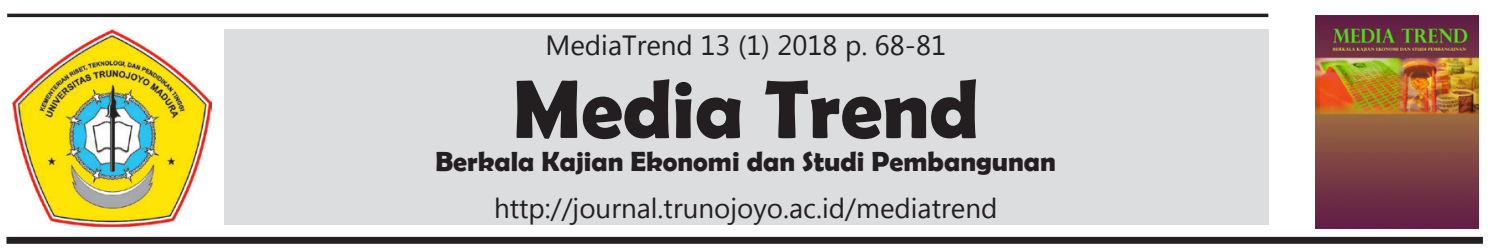

\title{
Faktor-Faktor Yang Mempengaruhi Keputusan Pembelian Konsumen Pada Swalayan Mikro Di Kota Semarang
}

\author{
Faris Nur Rohman ${ }^{1}$, Hendri Hermawan Adinugraha ${ }^{2 *}$ \\ ${ }^{1,2}$ Progam Studi Manajemen, Fakultas Ekonomi \& Bisnis, Universitas Dian Nuswantoro Semarang
}

\begin{tabular}{l} 
Informasi Artikel \\
\hline Sejarah artikel: \\
Diterima November 2017 \\
Disetujui Februari 2018 \\
Dipublikasikan Maret \\
2018 \\
\hline Keywords: \\
Location, \\
Physical Evidence, \\
Store Atmosphere, \\
The Variety of Merchan- \\
dise, \\
Purchase Decision
\end{tabular}

Informasi Artikel

Diterima November 2017

Disetujui Februari 2018

Dipublikasikan Maret

Keywords:

Store Atmosphere,

Purchase Decision

\begin{abstract}
A B S T R ACT
There is a big number of modern market in Indonesia. Based on the data, market share of Superindo, Hero, Griya and Micro Supermaarket have declined. Nevertheless, MICRO market share has declined the smallest and the lowest ranking. Based on this phenomenon, indicated there are problems which feasible to be analyzed. The object of this research is Micro Supermaarket Semarang. Many factors can influence purchasing decisions in Micro Supermarket Semarang, such as location, physical evidence, store atmosphere and the variety of merchandise. This study aims to analyze the influence of location, physical evidence, store atmosphere and the variety of merchandise on purchasing decision. The data population is consumers who make purchases at the Micro Supermarket Semarang and the samples taken 100 respondents. The type of data used primary data. Sampling technique used non-random type of purposive sampling. The methods of data collection using questionnaires and analysis techniques used multiple regression. The results show that location, physical evidence, store atmosphere and the variety of merchandise proved a positive and significant influence on purchasing decision.
\end{abstract}




\section{Pendahuluan}

Keberadaan pasar modern di Indonesia akan berkembang dari tahun ke tahun. Perkembangan yang pesat ini bisa jadi akan terus menekan keberadaan pasar tradisional pada titik terendah. Pasar modern yang notabene dimiliki oleh peritel asing dan konglomerat lokal akan menggantikan peran pasar tradisional yang mayoritas dimiliki oleh masyarakat kecil dan sebelumnya menguasai bisnis ritel di Indonesia.

Swalayan "ADA" diambil sebagai lokasi dalam penelitian ini karena Swalayan "ADA" merupakan representasi dari supermarket mikro yang ada di Semarang dan mempunyai kelebihan yaitu menawarkan pembelian dengan sistem pembayaran dengan kartu debit dan kartu kredit, sehingga meningkatkan angka penjualan. Alasan lainnya adalah selain menawarkan penjualan dengan sistem eceran, juga melayani penjualan grosir. Penjualan grosir itu cukup diminati terutama oleh para pedagang kecil yang kulakan.

Keputusan pembelian merupakan seleksi terhadap dua pilihan alternatif atau lebih konsumen pada pembelian (Schiffman dan Kanuk, 2008). Konsumen mempunyai pilihan antara melakukan pembelian dan tidak melakukan pembelian atau pilihan menggunakan waktu, maka konsumen tersebut berada dalam posisi untuk mengambil keputusan.

Banyak faktor yang dapat mempengaruhi keputusan pembelian. Menurut Nursanti dan Herlina (2012), Raf (2012), Rumagit (2013), Susilo dan Rengganis (2013), Antari, dkk (2014), Cahyani, dkk (2014), Kantohe dan Karuntu (2014), Machmud (2014), Widowati dan Purwanto (2014), Amir dan Prijati (2015), Autami dan Suasana (2015), Wahyuningsih dan Transistari (2015) serta Wakidah (2015) faktor-faktor yang mempengaruhi keputusan pembelian dapat diringkas menjadi empat variabel yaitu lokasi, bukti fisik, store atmosphere dan variasi merchandise.
Tujuan penelitian ini adalah untuk menganalisis pengaruh lokasi, bukti fisik, store atmosphere dan variasi merchandise terhadap keputusan pembelian di Swalayan "ADA"di Semarang.

\section{Tinjauan Pustaka \\ Keputusan Pembelian}

Keputusan pembelian adalah keputusan pembeli tentang merek mana yang dibeli (Kotler dan Amstrong, 2008). Konsep lain keputusan pembelian adalah seleksi terhadap dua pilihan alternatif atau lebih konsumen pada pembelian (Schiffman dan Kanuk, 2008). Kotler dan Keler (2009), mendeskripsikan keputusan pembelian adalah keputusan konsumen mengenai preferensi atas merek-merek yang ada di dalam kumpulan pilihan. Menurut Ginting (2012), keputusan pembelian adalah membeli merek yang paling dikehendaki konsumen.

Setiap hari konsumen mengambil berbagai keputusan mengenai setiap aspek kehidupan sehari-hari. Tetapi, kadang mengambil keputusan ini tanpa memikirkan bagaimana mengambil keputusan dan apa yang terlibat dalam proses pengambilan keputusan ini. Pilihan alternatif harus tersedia bagi seseorang ketika mengambil keputusan (Schiffman dan Kanuk, 2008).

Konsumen mempunyai pilihan antara melakukan pembelian dan tidak melakukan pembelian atau pilihan menggunakan waktu, maka konsumen tersebut berada dalam posisi untuk mengambil keputusan. Sebaliknya, jika konsumen tidak mempunyai alternatif untuk memilih dan benar-benar terpaksa melakukan pembelian tertentu atau mengambil tindakan tertentu, maka keadaan satu-satunya tanpa pilihan lain ini bukanlah suatu keputusan (Schiffman dan Kanuk, 2008).

\section{Lokasi}

Lokasi adalah tempat atau berdirinya perusahaan atau tempat usaha (Peter dan Olson, 2014). Deskripsi lain lo- 
kasi adalah keputusan yang dibuat perusahaan berkaitan dengan dimana operasi dan stafnya akan ditempatkan (Ratnasari dan Aksa, 2011).

Lokasi jasa seringkali tetap merupakan faktor krusial yang berpengaruh terhadap kesuksesan suatu jasa, karena lokasi erat kaitannya dengan pasar potensial penyedia jasa. Secara garis besar, ada dua kemungkinan pertimbangan dalam hal lokasi fasilitas jasa (Tjiptono, 2011)

Pentingnya memilih lokasi perusahaan jasa tergantung pada tipe dan derajat interaksi yang terlihat (Ratnasari dan Aksa, 2011). Lokasi berpengaruh terhadap dimensi-dimensi strategik, seperti fleksibilitas, competitive positioning, manajemen permintaan, dan fokus strategik. Fleksibilitas suatu lokasi merupakan ukuran sejauh mana sebuah jasa mampu bereaksi terhadap situasi perekonomian yang berubah. Keputusan pemilihan lokasi berkaitan dengan komitmen jangka panjang terhadap obyek-obyek yang sifatnya kapital intensif, karena itu penyedia jasa harus benar-benar mempertimbangkan, menyeleksi dan memilih lokasi yang responsif terhadap kemungkinan perubahan ekonomi, demografis, budaya, persaingan, dan peraturan di masa mendatang. Competitive positioning adalah metode-metode yang digunakan agar perusahaan dapat mengembangkan posisif relatifnya dibandingkan dengan pesaing. Misalnya jika perusahaan berhasil memperoleh dan mempertahankan lokasi yang banyak dan strategis (lokasi sentral dan utama), maka itu dapat menjadi rintangan efektif bagi para pesaing untuk mendapatkan akses ke pasar (Tjiptono, 2011).

\section{Bukti Fisik}

Bukti fisik adalah petunjuk visual atau berwujud lainnya yang memberi bukti atas kualitas jasa (Lovelock dan Wright, 2007). Definisi lain bukti fisik adalah lingkungan fisik perusahaan tempat jasa diciptakan dan tempat penyediaan jasa serta konsumen berinteraksi, ditambah elemen berwujud yang digunakan untuk mengkomunikasikan atau mendukung peranan jasa itu (Ratnasari dan Aksa, 2011).

Penampilan dan kemampuan sarana dan prasarana fisik perusahaan dan keadaan lingkungan sekitarnya adalah bukti nyata dari pelayanan yang diberikan oleh pemberi jasa, ini meliputi fasilitas fisik gedung, gudang, fasilitas fisik, dan lainnya, teknologi (peralatan dan perlengkapan yang dipergunakan), serta penampilan pegawainya (Ratnasari dan Aksa, 2011).

Bukti fisik adalah kemampuan suatu perusahaan dalam menunjukkan eksistensinya kepada pihak eksternal (Suryani, 2013). Penampilan kantor dan karyawan, kemampuan sarana dan prasarana fisik perusahaan (termasuk fasilitas komunikasi), serta lingkaran sekitarnya adalah bukti nyata dari pelayanan yang diberikan oleh pemberi jasa (Suryani, 2013).

\section{Store Atmosphere (Suasana Toko)}

Store atmosphere merupakan persepsi suasana toko sebagai akibat dari pengaruh efek-efek yang diciptakan pengusaha untuk membuat suatu toko agar menarik untuk dikunjungi oleh konsumen, yang tercipta dari gabungan unsur-unsur desain eksterior (interior gerai, visual, jalan masuk, pencahayaan), atmosfer serta layout (tata letak) (Nursanti dan Herlina, 2012). Pengertian lain store atmosphere merupakan suasana yang tercipta dari gabungan unsur-unsur desain toko/gerai, perencanaan toko, komunikasi visual, dan merchandising (Kantohe dan Karuhu, 2014). Definisi lain store atmosphere adalah suasana setiap toko yang mempunyai tata letak fisik yang memudahkan untuk berputar-putar di dalamnya (Amir dan Prijati, 2015).

Atmosfer toko memiliki efek signifikan pada perilaku karena keadaan emosi tersebut sulit diungkapkan secara verbal oleh konsumen. Keadaan emosi tersebut bersifat sementara dan memengaruhi 
perilaku dalam toko dengan cara yang mungkin tidak disadari oleh konsumen (Peter dan Olson, 2014).

Variasi Merchandise (Barang Dagangan) Variasi merchandise adalah produkproduk yang dijual peritel atau pengecer dalam gerainya (Nursanti dan Herlina, 2012). Konsep lain variasi merchandise atau pengelolaan barang dagangan adalah proses penanganan kreatif dalam upaya mempresentasikan atau menampilkan produk (barang dagangan) dengan tujuan memaksimalkan daya tarik penjualan ritel (Cahyani, dkk, 2014). Pengertian lain variasi merchandise adalah upaya pengadaan dan penanganan barang dagangan (Widowati dan Purwanto, 2014).

Variasi merchandise yang akan dijual penting dipilih dengan benar karena merupakan mesin sukses bagi pengecer. Keragaman produk terdiri atas dua hal yaitu banyak variasi kategori produk yang dijual, dan banyaknya item pilihan dalam masing-masing kategori produk (Nursanti dan Herlina, 2012).
Variasi merchandise adalah suatu presentasi nonpersonal dan pameran barang dagangan, dengan penjelasan rinci. Pendekatan ini untuk mendapatkan kepastian mengenai penampilan produk secara optimal, memperlengkapi pameran yang akan meningkatkan penyajian produk dan menggugah minat beli, melengkapi kegiatan penjualan dan informasi produk seperti dengan brosur dan posterposter, menjamin ketersediaan barang, meningkatkan penambahan penjualan melalui rangsangan pembelian atau dengan mengingatkan si pembeli apa yang akan didapat berdasarkan slogan produk tersebut (Widowati dan Purwanto, 2014).

Peritel harus mampu mengantisipasi perubahan-perubahan yang terjadi di dalam pasar dan tanggap mengadaptasikannya ke dalam bisnisnya, sehingga sesuai dengan gaya hidup. Bentuk dan konsep-konsep baru serta ide-ide kreatif mengenai bagaimana berbelanja dengan lebih nyaman dan menyenangkan dengan lokasi mudah dicapai dan memiliki poin yang menarik bagi konsumen yang patut dipertimbangkan (Nursanti dan Herlina, 2012).

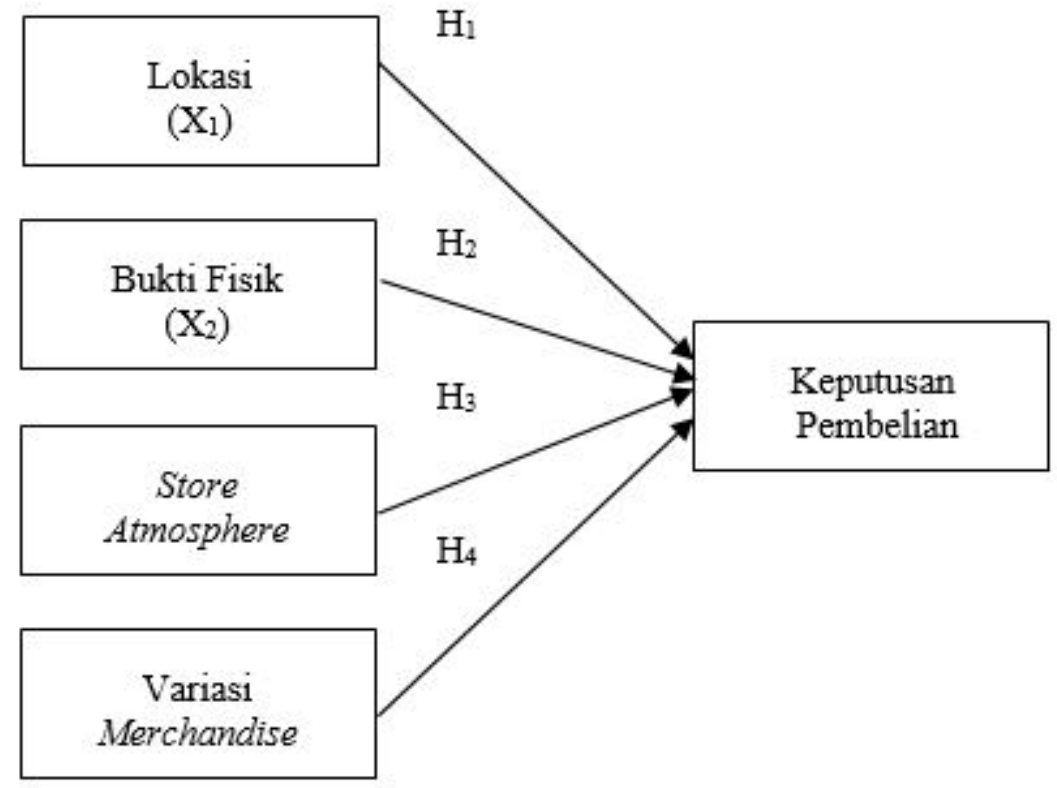

Gambar 1.

Kerangka Pemikiran 


\section{Kerangka Konseptual}

Keputusan pembelian merupakan membeli merek yang paling dikehendaki konsumen. Konsumen mempunyai pilihan antara melakukan pembelian dan tidak melakukan pembelian atau pilihan menggunakan waktu, maka konsumen tersebut berada dalam posisi untuk mengambil keputusan. Sebaliknya, jika konsumen tidak mempunyai alternatif untuk memilih dan benar-benar terpaksa melakukan pembelian tertentu atau mengambil tindakan tertentu, maka keadaan satu-satunya tanpa pilihan lain ini bukanlah suatu keputusan. Keputusan pembelian konsumen dapat dipengaruhi oleh berbagai faktor, seperti lokasi, bukti fisik, store atmosphere dan variasi merchandise. Dari uraian di atas, maka dapat dibuat kerangka pemikiran pada gambar 1 .

\section{Hipotesis}

$\mathrm{H}_{1}$ : Lokasi berpengaruh positif dan sig nifikan terhadap Keputusan Pembelian

$\mathrm{H}_{2}$ : Bukti Fiskk berpengaruh positif dan signifikan terhadap Keputusan Pembelian.

$\mathrm{H}_{3}$ : Store Atmosphere berpengaruh positif dan signifikan terhadap Keputusan Pembelian.

$\mathrm{H}_{4}$ : Variasi Merchandise berpengaruh positif dan signifikan terhadap Keputusan Pembelian

\section{Metode Penelitian \\ Variabel Penelitian}

Variabel dalam penelitian ini terdiri dari : Variabel bebas (independent), yaitu variabel yang mempengaruhi variabel lain dalam penelitian (Umar, 2013). Variabel penelitian terdiri dari variabel independen yaitu :

\section{Lokasi $\left(\mathbf{X}_{1}\right)$}

Lokasi merupakan keputusan yang dibuat perusahaan berkaitan dengan dimana operasi dan stafnya akan ditempatkan
(Ratnasari dan Aksa, 2011). Lokasi diukur melalui ; Lokasi strategis (mudah dilihat dan mudah dijangkau), Keamanan di lokasi terjamin, Lokasi luas, Lokasi parkir memadai dan Sarana transportasi. (Rumagit, 2013).

\section{Bukti Fisik $\left(X_{2}\right)$}

Bukti fisik adalah lingkungan fisik perusahaan tempat jasa diciptakan dan tempat penyediaan jasa serta konsumen berinteraksi, ditambah elemen berwujud yang digunakan untuk mengkomunikasikan atau mendukung peranan jasa itu (Ratnasari dan Aksa, 2011). Bukti Fisik dapat diukur melalui ; Karyawan menggunakan atribut (seragam kerja), Peralatan kerja mendukung (komputer dan monitor CCTV), Tersedia toilet bagi pengunjung, Tersedia escalator dan Gedung megah dan kokoh. (Wahyuningsih dan Transsistari, 2015)

\section{Store Atmosphere $\left(\mathrm{X}_{3}\right)$}

Store atmosphere merupakan persepsi suasana toko sebagai akibat dari pengaruh efek-efek yang diciptakan pengusaha untuk membuat suatu toko agar menarik untuk dikunjungi oleh konsumen, yang tercipta dari gabungan unsur-unsur desain eksterior (interior gerai, visual, jalan masuk, pencahayaan), atmosfer serta layout (tata letak) (Nursanti dan Herlina, 2012). Store atmosphere dapat diukur melalui ; Interior bangunan menarik, Penempatan barang yang mudah dicari (lay out), Sirkulasi ruang di toko memudahkan pengunjung bergerak, Suasana dalam toko nyaman (sejuk) serta Aroma dalam toko harum. (Kantohe dan Karuntu, 2014).

\section{Merchandise $\left(\mathrm{X}_{4}\right)$}

Merchandise adalah produk-produk yang dijual peritel atau pengecer dalam gerainya (Nursanti dan Herlina, 2012). Merchandise dapat diukur dengan indikator ; Produk yang ditawarkan lengkap, Jenis produk yang ditawarkan beragam, Jumlah merek yang ditawarkan bervariasi, Variasi ukuran / kemasan produk yang ditawarkan dan Jumlah persediaan cukup. (Kantohe dan Karuntu, 2014). Variabel terikat (de- 
pendent), yaitu variabel yang dipengaruhi oleh variabel lain (Umar, 2013). Variabel terikat yang digunakan adalah

\section{Keputusan Pembelian (Y)}

Keputusan pembelian merupakan seleksi terhadap dua pilihan alternatif atau lebih konsumen pada pembelian (Schiffman dan Kanuk, 2008). Keputusan pembelian diukur melalui ; produk yang ditawarkan sesuai dengan kebutuhan, Kemudahan untuk mendapatkan barang, Kemudahan untuk membeli barang, Keinginan untuk membeli kembali dan Rekomendasi. (Widowati dan Purwanto, 2014)

\section{Obyek Penelitian}

Obyek penelitian ini adalah Pasar Swalayan "ADA" di kota Semarang. Alasan menggunakan Swalayan "ADA" karena dari dulu hingga sekarang masih tetap bertahan bahkan selalu mengembangkan usahanya di setiap sudut arah dari luar maupun ke dalam kota Semarang. Swalayan "ADA" mempunyai cara tersendiri untuk memenangkan persaingan dalam menjaring konsumen sebanyakbanyaknya.

\section{Populasi dan Sampel}

Populasi dalam penelitian ini adalah konsumen yang melakukan pembelian di Pasar Swalayan "ADA" Semarang. Sampel dalam penelitian ini adalah sebagian konsumen yang melakukan pembelian di Pasar Swalayan "ADA" Semarang. dan diperoleh sampel 100 sampel.

\section{Jenis Data dan Sumber Data}

Jenis data dalam penelitian ini adalah data primer. Data primer adalah yaitu data yang didapat dari sumber pertama baik dari individu atau perseorangan (Umar, 2013).

\section{Metode Pengumpulan Data}

Metode pengumpulan data yang digunakan adalah angket atau kuesioner. Kuesioner adalah merupakan suatu pengumpulan data dengan memberikan atau menyebarkan daftar pertanyaan/pernyataan kepada responden dengan harapan memberikan respon atas daftar pertanyaan tersebut (Umar, 2013).

\section{Metode Analisis}

Metode analisis data yang digunakan adalah Regresi Berganda

Regresi berganda digunakan untuk mengukur kekuatan hubungan antara dua variabel atau lebih, juga menunjukkan arah hubungan antara variabel dependen dengan variabel independen (Ghozali, 2009).

Rumus (Ghozali, 2009)

$\mathrm{Y}=\mathrm{b}_{0}+\mathrm{b}_{1} \mathrm{X}_{1}+\mathrm{b}_{2} \mathrm{X}_{2}+\mathrm{b}_{3} \mathrm{X}_{3}+\mathrm{b}_{4} \mathrm{X}_{4}+\mathrm{e}$

Dimana $Y$ merupakan Keputusan Pembelian, bo merupakan Konstanta, b1, b2, b3 dan b4 merupakan Koefisien Regresi, $X_{1}$ Lokasi, $\mathrm{X}_{2}$ Bukti Fisk, $\mathrm{X}_{3}$ Store Atmosphere, $\mathrm{X}_{4}$ Merchandise, serta e adalah error

\section{Hasil Penelitian dan Pembahasan Hasil Regresi}

Berdasarkan dari hasil regresi maka dapat dibuat persamaan linear sebagai berikut :

$\mathrm{Y}=0,327+0,191 \mathrm{X} 1+0,268 \mathrm{X} 2+0,222$ $\mathrm{X} 3+0,271 \mathrm{X} 4$

Berdasarkan hasil persamaan regresi diatas mengandung pengertian sebagai berikut : (1) Konstanta $(\alpha)=0,327$, dapat diartikan bahwa apabila lokasi, bukti fisik, store atmosphere, dan variasi merchandise bermilai nol maka keputusan pembelian bernilai positif. (2) Koefisien regresi lokasi $(b 1)=0,191$, nilai positif yang didapat menunjukkan bahwa setiap ada lokasi yang lebih baik maka akan meningkatkan keputusan pembelian. (3) Koefisien regresi bukti fisik (b2) $=0,268$, nilai positif yang didapat menunjukkan bahwa setiap ada peningkatan bukti fisik akan meningkatkan keputusan pembelian. (4) Koefisien regresi store atmosphere (b3) $=0,222$, nilai positif yang didapat menunjukkan bahwa setiap ada peningkatan store atmosphere 
Tabel 1.

Regresi Berganda

Coefficients ${ }^{a}$

\begin{tabular}{|c|c|c|c|c|c|c|}
\hline \multirow{2}{*}{\multicolumn{2}{|c|}{ Model }} & \multicolumn{2}{|c|}{$\begin{array}{c}\text { Unstandardized } \\
\text { Coefficients }\end{array}$} & \multirow{2}{*}{$\begin{array}{c}\text { Standardized } \\
\text { Coefficients } \\
\text { Beta }\end{array}$} & \multirow[t]{2}{*}{$t$} & \multirow[t]{2}{*}{ Sig. } \\
\hline & & $\mathrm{B}$ & Std. Error & & & \\
\hline \multirow{5}{*}{1} & (Constant) & .738 & .404 & & 1,828 & .071 \\
\hline & Lokasi &,- 080 &, 049 &,- 394 & $-1,642$ &, 104 \\
\hline & Bukti Fisik & .101 & .068 & .445 & 1,543 & .126 \\
\hline & Store Atmosphere & .074 & .055 & .355 & 1,330 & .187 \\
\hline & Variasi Merchandise &,- 080 &, 051 &,- 373 & $-1,559$ &, 122 \\
\hline
\end{tabular}

a. Dependent Variable: ABS_RES

Sumber : Data Primer Diolah, 2017

akan meningkatkan keputusan pembelian. (5) Koefisien regresi variasi merchandise (b3) $=0,271$, nilai positif yang didapat menunjukkan bahwa setiap ada peningkatan variasi merchandise akan meningkatkan keputusan pembelian.

\section{Koefisien Determinasi}

Besarnya koefisien determinasi dapat dilihat pada Adjusted $R$ Square sebesar 0,865 . Hasil ini mengandung pengertian bahwa kemampuan lokasi, bukti fisik, store atmosphere, dan variasi merchandise dalam menjelaskan keputusan pembelian adalah sebesar $86,5 \%(0,865 \times 100 \%)$, sementara $13,5 \%(100 \%-86,5 \%)$ keputusan pembelian dijelaskan oleh faktor- faktor lain di luar lokasi, bukti fisik, store atmosphere, dan variasi merchandise.

Uji - F

Hasil uji - F sebesar 159,255 dengan sig. 0,000. Nilai sig. lebih kecil $(<)$ dari 0,05 , yang menunjukkan bahwa lokasi, bukti fisik, store atmosphere dan variasi merchandise berpengaruh terhadap keputusan pembelian secara bersama-sama. Hal ini berarti lokasi, bukti fisik, store atmosphere dan variasi merchandise menjadi variabel yang secara bersama-sama dipertimbangkan para konsumen ketika ingin melakukan pembelian di Swalayan "ADA" Semarang.

Tabel 2.

Hasil Koefisien Determinasi

Model Summary ${ }^{b}$

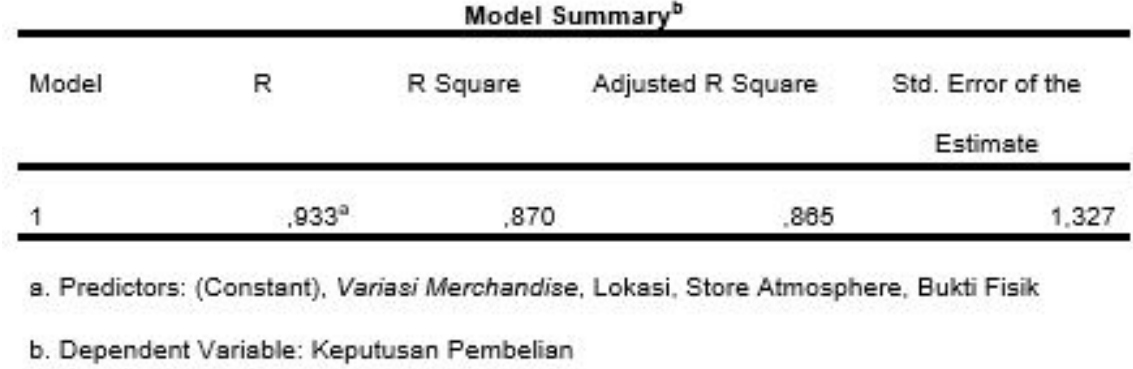

Sumber : Data Primer Diolah, 2017 
Tabel 1.

Regresi Berganda

ANOVA:

\begin{tabular}{|c|c|c|c|c|c|}
\hline Model & Sum of Squares & df & Mean Square & $\mathrm{F}$ & Sig. \\
\hline Regression & 1121,682 & 4 & 280,420 & 159,255 & $.000^{\circ}$ \\
\hline 1 Residual & 167,278 & 95 & 1,761 & & \\
\hline Total & 1288,960 & 99 & & & \\
\hline
\end{tabular}

a. Dependent Variable: Keputusan Pembelian

b. Predictors: (Constant), Variasi Merchandise, Lokasi, Store Atmosphere, Bukti Fisik

Sumber : Data Primer Diolah, 2017

$\mathrm{Uji}-\mathbf{t}$

Berdasarkan hasil uji - $t$ diatas dapat dilakukan analisa sebagai berikut : (1) Hasil uji - t lokasi terhadap keputusan pembelian sebesar 2,310 dengan sig. $0,023<0,05$, sehingga menerima hipotesis yang menyatakan lokasi berpengaruh positif dan signifikan terhadap keputusan pembelian. (2) Hasil uji - $t$ bukti fisik terhadap keputusan pembelian sebesar 2,401 dengan sig. 0,018<0,05, sehingga menerima hipotesis yang menyatakan bukti fisik berpengaruh positif dan signifikan terhadap keputusan pembelian. (3) Hasil uji - $t$ store atmosphere terhadap keputusan pembelian sebesar 2,366 dengan sig. $0,020<0,05$, sehingga menerima hipotesis yang menyatakan store atmosphere berpengaruh positif dan signifikan terhadap keputusan pembelian. (4) Hasil uji - $\mathrm{t}$ variasi merchandise terhadap keputusan pembelian sebesar 3,129 dengan sig. $0,002<0,05$, sehingga menerima hipotesis yang menyatakan variasi merchandise berpengaruh positif dan signifikan terhadap keputusan pembelian.

Tabel 1.

Regresi Berganda

\begin{tabular}{llll}
\hline Model & t & Sig. & \\
& &, 477 & .634 \\
(Constant) & 2,310 & .023 \\
& Lokasi & 2,401 & .018 \\
& Store Atmosphere & 2,368 & .020 \\
Variasi & & .002 \\
\hline
\end{tabular}

a. Dependent Variable: Keputusan Pembelian

Sumber : Data Primer Diolah, 2017 


\section{Pembahasan \\ Lokasi Berpengaruh Positif Terhadap Keputusan Pembelian}

Uji hipotesis membuktikan bahwa lokasi berpengaruh positif terhadap keputusan pembelian, dengan didapat hasil uji - t sebesar 2,310 dan sig. 0,023 < 0,05. Hasil positif yang didapat menunjukkan bahwa setiap ada lokasi yang strategis dan didukung oleh sarana yang memadai maka akan meningkatkan keputusan pembelian di Swalayan ADA Semarang. Lokasi adalah tempat atau berdirinya perusahaan atau tempat usaha (Peter dan Olson, 2014: 268). Dengan lokasi yang strategis seperti mudah dijangkau dengan berbagai alat transportasi dan berada di pinggir jalan raya akan menarik minat konsumen untuk datang melakukan pembelian.

Penelitian yang dilakukan memperlihatkan bahwa konsumen memberikan persepsi yang baik terhadap lokasi Swalayan ADA Semarang (nilai rata-rata 3,42 ). Persepsi yang baik didasari karena penilaian tinggi mengenai lokasi Swalayan "ADA" Semarang strategis (mudah dilihat dan mudah dijangkau) (nilai rata-rata 3,50 ). Setiap lokasi Swalayan ADA Semarang berada di pinggir jalan raya utama di Kota Semarang. Konsumen memberikan penilaian tinggi mengenai lokasi Swalayan "ADA" Semarang luas (nilai rata-rata 3,48 ). Setiap lokasi menyisahkan tempat untuk tempat parkir dan pintu keluar masuk ke dalam toko yang lebar sehingga cukup luas dan membuat konsumen nyaman masuk atau keluar dari Swalayan ADA. Penilaian tinggi juga diberikan mengenai sarana transportasi di Swalayan "ADA" Semarang mudah (nilai rata-rata 3,47 ). Banyak sarana transportasi untuk menuju lokasi Swalayan ADA baik kendaraan pribadi maupun transportasi seperti Taxi, bus, angkot dan yang lewat didepan lokasi Swalayan ADA. Sementara itu untuk lokasi para konsumen memberikan penilaian cukup mengenai lokasi di Swalayan "ADA" Semarang keamanannya terjamin (nilai rata-rata 3,31 ).
Keamanan di Swalayan ADA didukung oleh tenaga kemanan dan kamera CCTV tetapi belum menjamin keamanan konsumen terutama keamanan barang yang dibawa. Konsumen juga memberikan penilaian cukup mengenai lokasi tempat parkir Swalayan "ADA" Semarang memadai (nilai rata-rata 3,32). Rata-rata lokasi Swalayan ADA memiliki tempat parkir yang luas tetapi diantaranya belum didukung oleh prasarana yang memadai.

Berdasarkan dari penilaian konsumen terhadap lokasi maka untuk lokasi masih perlu didukung oleh keamanan yang terjamin, seperti tenaga keamanan yang sering berkeliling tidak hanya fokus di dalam gedung, dan setiap pengunjung yang keluar tempat parkir menujukkan STNK sehingga dapat menghindari pencurian kendaraan. Selain itu untuk tempat parkir yang berada diluar diberi atap atau kanopi agar dapat menghindari panas dan hujan sehingga memberi kenyamanan bagi konsumen. Dengan sarana yang memberi kemananan dan kenyamanan maka hal ini yang akan membuat konsumen berkeinginan untuk datang berbelanja di Swalayan ADA.

Hasil penelitian yang didapat mendukung penelitian Raf (2012), Rumagit (2013), Antari, dkk (2014), Machmud (2014), Widowati dan Purwanto (2014) serta Wakidah (2015) yang menunjukkan bahwa lokasi berpengaruh terhadap keputusan pembelian.

\section{Bukti Fisik Berpengaruh Positif Terha- dap Keputusan Pembelian}

Uji hipotesis membuktikan bahwa

bukti fisik berpengaruh positif terhadap keputusan pembelian, dengan didapat hasil uji - t sebesar 2,401 dan sig. 0,018< 0,05 . Hasil positif yang didapat menunjukkan bahwa setiap ada kondisi fisik yang mendukung pelayanan lebih baik maka akan meningkatkan keputusan pembelian di Swalayan ADA Semarang. Bukti fisik adalah lingkungan fisik perusahaan tem- 
pat jasa diciptakan dan tempat penyediaan jasa serta konsumen berinteraksi, ditambah elemen berwujud yang digunakan untuk mengkomunikasikan atau mendukung peranan jasa itu (Ratnasari dan Aksa, 2011: 52). Dengan bukti fisik yang mendukung pelayanan lebih baik kepada konsumen pada saat melakukan transaksi, maka akan membuat konsumen berkeinginan untuk melakukan pembelian produk atau jasa yang ditawarkan oleh penjual.

Penelitian yang dilakukan memperlihatkan bahwa konsumen memberikan persepsi yang baik terhadap bukti fisik yang dimiliki Swalayan ADA Semarang (nilai rata-rata 3,48 ). Persepsi yang baik didasari karena penilaian tinggi mengenai Swalayan "ADA" Semarang memiliki peralatan kerja yang mendukung seperti komputer dan monitor CCTV (nilai ratarata 3,47 ). Peralatan komputer digunakan untuk berbagai proses kerja seperti memproses transaksi pembayaran dari para konsumen, sementara untuk monitor CCTV memantau keamanan di sekitar gedung. Persepsi yang baik juga diberikan mengenai Swalayan "ADA" Semarang tersedia toilet bagi pengunjung (nilai ratarata 3,67). Didalam gedung Swalayan ADA tersedia toilet untuk memenuhi kebutuhan kamar kecil bagi para konsumen ketika berada di gedung Swalayan ADA. Persepsi yang baik juga diberikan mengenai Swalayan "ADA"tersedia eskalator (tangga berjalan) (nilai rata-rata 3,68 ), sehingga konsumen tidak perlu melangkahkan kaki untuk menaiki atau menuruni anak tangga. Sementara itu konsumen memberikan penilaian cukup terhadap bukti fisik mengenai karyawan Swalayan "ADA"menggunakan atribut (seragam) yang rapi dan sopan (nilai rata-rata 3,26 ). Para karyawan menggunakan seragam yang rapi dan cukup sopan ketika dipakai. Penilaian cukup juga diberikan mengenai gedung Swalayan "ADA" Semarang megah dan kokoh (nilai rata-rata 3,31). Bangunan gedung terlihat besar dan kuat tetapi ketika berada didalam masih kurang luas atau terkesan sempit. Berdasarkan persepsi konsumen terhadap bukti fisik maka perlu ada perubahan atau peningkatan yang lebih baik seperti dalam hal berpakaian sebaiknya untuk karyawan wanita menggunakan pakaian lengan panjang dan bercelana panjang agar terlihat lebih tertutup dan sopan dalam berpenampilan. Selain itu mempertimbangkan untuk memperluas bagian dalam gedung sehingga akan terlihat lebih luas dan megah. Dengan bukti fisik yang lebih baik maka akan membuat konsumen tertarik untuk datang melakukan pembelian di Swalayan "ADA"Semarang.

Hasil penelitian yang didapat mendukung penelitian Susilo dan Rengganis (2013), Machmud (2014) serta Wahyuningsih dan Transistari (2015) yang menunjukkan bahwa bukti fisik berpengaruh terhadap keputusan pembelian.

\section{Store Atmosphere Berpengaruh Positif Terhadap Keputusan Pembelian}

Uji hipotesis membuktikan bahwa store atmosphere berpengaruh positif terhadap keputusan pembelian, dengan didapat hasil uji - t sebesar 2,366 dan sig. $0,020<0,05$. Hasil positif yang didapat menunjukkan bahwa dengan store atmosphere yang memberi kenyamanan maka akan meningkatkan keputusan pembelian di Swalayan ADA Semarang. Store atmosphere merupakan persepsi suasana toko sebagai akibat dari pengaruh efek-efek yang diciptakan pengusaha untuk membuat suatu toko agar menarik untuk dikunjungi oleh konsumen, yang tercipta dari gabungan unsur-unsur desain eksterior (interior gerai, visual, jalan masuk, pencahayaan), atmosfer serta layout (tata letak) (Nursanti dan Herlina, 2012: 359). Dengan membuat suasana toko yang membuat konsumen merasa tenang dan betah maka akan membuat mereka berkeinginan untuk selalu datang melakukan pembelian.

Penelitian yang dilakukan memperlihatkan bahwa konsumen memberikan pe- 
nilaian cukup terhadap Store Atmosphere yang dimiliki Swalayan ADA Semarang (nilai rata-rata 3,32 ). Penilaian cukup didasari karena penilaian cukup mengenai interior bangunan (display, tata warna, pencahayaan) Swalayan "ADA" Semarang menarik (nilai rata-rata 3,30 ). Penataan dilakukan dengan menempatkan produk di berbagai display dan disesuaikan dengan jenisnya, tetapi penataan display masih terlihat padat sehingga membuat ruangan terlihat sempit, sementara untuk warna dinding menggunakan warna yang cerah dan menggunakan pencahayaan yang terang sehingga dapat melihat dengan jelas setiap produk yang terdapat di display. Penilaian cukup juga diberikan terhadap penataan dalam ruangan Swalayan "ADA" Semarang memudahkan konsumen untuk bergerak mencari barang (nilai rata-rata $3,19)$. Letak antara satu display dengan display lain khususnya untuk produk rumah tangga masih terlalu dekat, sehingga memberi rasa kurang nyaman konsumen untuk bergerak dari satu display ke display lain apalagi jika pada saat bersamaan banyak konsumen yang datang melakukan pembelian. Penilaian cukup juga diberikan mengenai suasana aroma di dalam Swalayan "ADA" Semarang harum (nilai ratarata 3,18 ). Didalam ruang belum tersedia pengharum ruangan, sementara bau harum dapat tercium dari beberapa produk yang menimbulkan bau harum seperti sabun, pewangi, dan sebagainya. Sementara itu konsumen memberikan penilaian tinggi mengenai penempatan barang di Swalayan "ADA"mudah mencarinya (nilai rata-rata 3,44). Masing - masing barang ditempatkan di display yang berbeda dan diberi keterangan atau papan nama sehingga konsumen mudah untuk mendapatkan tempat produk yang akan dibeli. Penilaian tinggi juga diberikan mengenai suasana di dalam Swalayan "ADA"Semarang nyaman (sejuk) (nilai rata-rata 3,51). Didalam Swalayan ADA terdapat pendingin udara (AC) sehingga suasana didalam gedung berasa sejuk

Berdasarkan dari penilaian konsumen terhadap store atmosphere masih perlu ditingkatkan mengenai penataan interior yang menarik yaitu untuk display ditempatkan di pinggir dan jangan banyak yang ditengah karena dapat mengganggu akses jalan bagi konsumen sehingga membuat jalan didalam ruangan menjadi lebih sempit. Sementara untuk display khusus produk rumah tangga jaraknya dibuat lebih lebar sehingga membuat konsumen leluasa bergerak dari satu ke display lain untuk mengambil produk yang dibutuhkan. Selain itu didalam gedung juga dipasang pengharum ruangan otomatis yang dapat mengeluarkan aroma harum setiap beberapa menit. Dengan membuat suasana toko yang lebih nyaman maka akan membuat konsumen berkeinginan berbelanja di Swalayan ADA.

Hasil penelitian yang didapat mendukung penelitian Nursanti dan Herlina (2012), Kantohe dan Karuhu (2014), Amir dan Prijati (2015) serta Autami dan Suasana (2015) yang menunjukkan bahwa store atmosphere berpengaruh terhadap keputusan pembelian.

\section{Variasi merchandise Berpengaruh Posi- tif Terhadap Keputusan Pembelian}

Uji hipotesis membuktikan bahwa variasi merchandise berpengaruh positif terhadap keputusan pembelian, dengan didapat hasil uji - t sebesar 3,129 dan sig. $0,002<0,05$. Hasil positif yang didapat menunjukkan bahwa dengan variasi merchandise yang lebih lengkap sesuai kebutuhan konsumen maka akan meningkatkan keputusan pembelian di Swalayan ADA Semarang. Variasi merchandise atau pengelolaan barang dagangan adalah proses penanganan kreatif dalam upaya mempresentasikan atau menampilkan produk (barang dagangan) dengan tujuan memaksimalkan daya tarik penjualan ritel (Cahyani, dkk, 2014: 4). Dengan pengemasan variasi merchandise yang menarik 
maka akan membuat konsumen berminat melakukan pembelian.

Penelitian yang dilakukan memperlihatkan bahwa konsumen memberikan penilaian cukup terhadap variasi merchandise yang dimiliki Swalayan ADA Semarang (nilai rata-rata 3,34). Penilaian cukup didasari karena penilaian cukup mengenai jenis produk yang ditawarkan oleh Swalayan "ADA" Semarang beragam (kecil, menengah dan besar) (nilai ratarata 3,29 ). Hal ini menunjukkan untuk jenis produk masih terbatas seperti untuk produk hanya memiliki ukuran tertentu saja yaitu hanya kecil atau besar saja seperti untuk ukuran produk makanan dan minuman. Penilaian cukup juga diberikan mengenai Swalayan "ADA" Semarang menawarkan produk dengan ukuran/kemasan yang bervariasi (nilai rata-rata 3,23). Variasi ukuran produk juga masih terbatas seperti produk fashion atau sepatu hanya tersedia nomor ukuran tertentu. Penilaian cukup diberikan pula mengenai Swalayan "ADA"Semarang menawarkan produk dengan jumlah persediaan yang cukup (nilai rata-rata $3,25)$. Hal ini karena terkadang stok terbatas sehingga sudah cepat habis ketika banyak konsumen yang melakukan pembelian. Sementara itu konsumen memberikan penilaian tinggi mengenai Swalayan "ADA"Semarang menawarkan produk yang lengkap (pakaian, mainan, sepatu) (nilai rata-rata 3,46 ), sehingga konsumen dapat membeli berbagai kebutuhan untuk aktivitas sehari-hari seperti pakaian dan sepatu serta hiburan untuk anak yaitu mainan hanya di satu lokasi saja. Konsumen juga memberikan penilaian tinggi juga mengenai jumlah merek produk yang ditawarkan Swalayan "ADA"Semarang bervariasi (nilai rata-rata 3,49). Masing - masing produk ditawarkan lebih dari satu merek sehingga menawarkan berbagai merek yang cocok digunakan konsumen.

Berdasarkan dari penilaian konsumen terhadap variasi merchandise perlu ditingkatkan jenis produk yang lebih bera- gam yaitu apabila satu item memiliki jenis variasi yang berbeda, maka perlu dilengkapi ukurannya sehingga dapat memenuhi kebutuhan ukuran konsumen yang berbeda terhadap satu item produk. Variasi ukuran produk juga lebih dilengkapi seperti untuk ukuran pakaian dijual lengkap yaitu $S, M, L$, dan $X L$ sehingga konsumen bisa mendapatkan pakaian yang diinginkan dari segi model dan ukuran. Swalayan ADA juga harus menyediakan persediaan yang cukup, yaitu ketika ada stok produk yang menipis atau hampir habis harus melakukan order lagi untuk dikirm secepatnya agar tidak kehabisan yang dapat membuat konsumen kecewa karena produk yang dibutuhkan tidak tersedia. Dengan menyediakan variasi merchandise yang lebih memenuhi kebutuhan konsumen maka akan membuat konsumen akan memilih melakukan pembelian di Swalayan ADA.

Hasil penelitian yang didapat mendukung penelitian Nursanti dan Herlina (2012), Cahyani, dkk (2014) serta Autami dan Suasana (2015) yang menunjukkan bahwa variasi merchandise berpengaruh terhadap keputusan pembelian.

\section{Penutup}

Berdasarkan dari hasil penelitian dampak lokasi, bukti fisik, store atmosphere, dan variasi merchandise pada keputusan pembelian di Swalayan ADA Semarang, dapat ditarik kesimpulan bahwa variasi merchandise menjadi faktor terbesar yang mempengaruhi keputusan pembelian di Swalayan "ADA" Semarang, sehingga apabila jumlah merek produk yang ditawarkan Swalayan "ADA" Semarang bervariasi, Swalayan "ADA" Semarang menawarkan produk yang lengkap (pakaian, mainan, sepatu), jenis produk yang ditawarkan oleh Swalayan "ADA" Semarang beragam (kecil, menengah, dan besar), Swalayan "ADA" Semaramg menawarkan produk dengan ukuran/kemasan yang bervariasi maka akan meningkatkan keputusan pembelian konsumen. Bukti fisik men- 
jadi faktor kedua yang mempengaruhi keputusan pembelian di Swalayan "ADA" Semarang, sehingga apabila Swalayan "ADA" Semarang tersedia eskalator (tangga berjalan) untuk memudahkan pengunjung, Swalayan "ADA" Semarang tersedia toilet bagi pengunjung, Swalayan "ADA" Semarang memiliki peralatan kerja yang mendukung seperti komputer dan monitor CCTV, gedung Swalayan "ADA" Semarang megah dan kokoh, maka akan meningkatkan keputusan pembelian konsumen. Store atmosphere menjadi faktor ketiga yang mempengaruhi keputusan pembelian di Swalayan "ADA" Semarang, sehingga apabila suasana di dalam Swalayan "ADA" Semarang nyaman (sejuk), penempatan barang di Swalayan "ADA" Semarang mudah mencarinya, interior bangunan (display, tata warna, pencahayaan Swalayan "ADA" Semarang menarik, penataan ruang di Swalayan "ADA" Semarang memudahkan konsumen untuk bergerak mencari barang maka akan meningkatkan keputusan pembelian konsumen. Lokasi menjadi variabel terkecil yang mempengaruhi keputusan pembelian di Swalayan "ADA" Semarang, hasil ini dapat disimpulkan apabila lokasi Swalayan "ADA" Semarang strategis (mudah dilihat dan mudah dijangkau), lokasi di Swalayan "ADA" Semarang luas, sarana transportasi di Swalayan "ADA" Semarang mudah, lokasi di Swalayan "ADA" Semarang keamanannya terjamin maka akan meningkatkan keputusan pembelian konsumen.

\section{Daftar Pustaka}

Amir, Faishol dan Prijati. 2015. "Pengaruh Store Atmosphere Dan Harga Terhadap Keputusan Pembelian Konsumen Cosmic Clothing Store". Jurnal IImu dan Riset Manajemen. Vol. 4. No. 8. Hal. 1-18. Sekolah Tinggi Ilmu Ekonomi Indonesia (STIESIA) Surabaya.

Antari, Kadek Ria Mariska, Ketut Dunia dan Luh Indrayani. 2014. "Pengaruh Lokasi
Dan Harga Terhadap Keputusan Berbelanja Pada Mini Market Sastra Mas Tabanan". Jurnal Pendidikan Ganesha. Vol. 4. No. 1. Hal. 1-11. Singaraja. Bali.

Autami, Ni Luh Made Manasaputri Sri dan I Gusti Agung Ketut Gede Suasana. 2015. "Pengaruh Retail Mix Terhadap Keputusan Pembelian Konsumen Pada Gerai Chatime". Jurnal Manajemen Unud. Vol. 4. No. 11. Hal. 3882 - 3908. Universitas Udayana. Denpasar. Bali. Indonesia.

Cahyani, Dian Nur, Saryadi dan Widiartanto. 2014. "Pengaruh Store Planning, Merchandising Dan Keragaman Produk Terhadap Keputusan Pembelian Di Toko Buku Gramedia (Studi Kasus Pada Konsumen Toko Buku Gramedia Pandanaran Semarang)". Jurnal IImu Administrasi Bisnis. Hal. 1-11. UNDIP. Semarang.

Ghozali, Imam. 2009. Aplikasi Analisis Multivariate Dengan Program SPSS. Cetakan Keempat. Badan Penerbit Universitas Diponegoro. Semarang.

Ginting, Nembah F. Hartimbul. 2012. Manajemen Pemasaran. Cetakan 2. Yrama Widya. Bandung.

Kantohe, Junitrianto dan Merlyn Karuntu. 2014. "Faktor-Faktor Yang Mempengaruhi Konsumen Dalam Berbelanja Pada Fiesta Pasar Swalayan Manado". Jurnal Ekonomi Manajemen Bisnis dan Akuntansi (EMBA). Vol. 2. No. 1. Hal. 66-77. Universias Sam Ratulangi. Manado.

Kotler, Philip dan Gary Amstrong, 2008. Prinsip-Prinsip Pemasaran. Jilid 1. Edisi Keduabelas. Erlangga. Jakarta.

Kotler, Philip dan Kevin Lane Keller. 2009. Alih Bahasa : Benyamin Molan. Manajemen Pemasaran. Edisi Ketigabelas. Jilid 1. Cetakan Keempat. PT. Indeks. Jakarta. 
Lovelock, Christopher H. dan Lauren K. Wright. 2007. Manajemen Pemasaran Jasa. Cetakan II. Indeks. Jakarta.

Machmud, Amir. 2014. "Analisis FaktorFaktor Bauran Pemasaran Yang Mempengaruhi Keputusan Konsumen Berbelanja Ke Robinson Supermarket Di Samarinda". Journal Ilmu Adminstrasi Bisnis. Vol. 2. No. 3. Hal. 316 - 330. Universitas Mulawarman. Samarinda.

Nursanti, Tinjung Desy dan Herlina. 2012. "Analisis Pengaruh Suasana Toko, Variasi Merchandise, Dan Kualitas Pelayanan Terhadap Keputusan Pembelian Aksesoris Gadget: Studi Kasus Gerai Wellcommshop Mal Citraland". Jurnal Binus Business Review. Vol. 3. No. 1. Hal. 356-373. BINUS University. Jakarta.

Peter, J. Paul dan Jerry C. Olson. 2014. Perilaku Konsumen dan Strategi Pemasaran". Buku 4. Edisi 9. Salemba Empat. Jakarta.

Raf, Mulyadi. 2012. "Pengaruh Faktor-Faktor Memotivasi Konsumen Berbelanja Terhadap Keputusan Konsumen Berbelanja Di Pasar Modern Kota Jambi". Jurusan Manajemen Fakultas Ekonomi Universitas Jambi. Vol. 1. No. 1. Hal. 63-75. Universitas Jambi. Jambi.

Ratnasari, Ririn Tri dan Mastuti Aksa. 2011. Manajemen Pemasaran Jasa. Ghalia Indonesia. Bogor.

Rumagit, Richard R. 2013. "Bauran Penjualan Eceran (Retailing Mix) Pengaruhnya Terhadap Keputusan Pembelian Di Jumbo Swalayan Manado". Jurnal Ekonomi Manajemen Bisnis dan Akuntansi (EMBA). Vol. 1. No. 4. Hal. 171-181. Universitas Sam Ratulangi. Manado.

Schiffman, Leon dan Leslie Lazar Kanuk. 2008. Perilaku Konsumen. Edisi Ketujuh. Cetakan Keempat. PT. Indeks. Jakarta.
Suryani, Tatik 2013. Perilaku Konsumen di Era Internet. Implikasinya pada Strategi Pemasaran. Edisi Pertama. Cetakan Pertama. Graha IImu. Yogyakarta.

Susilo, Ade dan Renni Rengganis. 2013. "Pengaruh Bauran Pemasaran Jasa Terhadap Proses Keputusan Pembelian Pada Produk Operator Seluler IM3 (Studi Kasus Pada Mahasiswa Fakultas Komunikasi dan Bisnis Telkom University)". Jurnal Fakultas Komunikasi dan Bisnis Universitas Telkom. Hal. 1-11. Universitas Telkom. Bandung.

Tjiptono, Fandy. 2011. Pemasaran Jasa. Bayumedia Publishing. Yogyakarta.

Umar, Husein. 2013. Metode Penelitian untuk Skripsi dan Tesis Bisnis. Edisi Kedua. Cetakan Keduabelas. PT. Raja Grafindo Persada. Jakarta.

Wahyuningsih, Tri Harsini dan Ralina Transistari. 2015. "Pengaruh Bauran Pemasaran Terhadap Keputusan Pembelian Produk Asuransi Pada Wanita Pekerja". Efektif : Jurnal Bisnis dan Ekonomi. Vol. 6. No. 1. Hal. $73-88$. Sekolah Tinggi IImu Manajemen YKPN. Yogyakarta

Wakidah, Armin. 2015. "Pengaruh Keragaman Produk, Lokasi Dan Promosi Terhadap Keputusan Pembelian Di Indomaret ( Study Kasus Pada Konsumen Indomaret Jalan Kh. Ahmad Dahlan No.71 Cabang Kota Kediri )". Artikel Universitas Nusantara PGRI Kediri. Hal. 1-20. Universitas Nusantara PGRI Kediri.

Widowati, Maduretno dan Agus Budi Purwanto. 2014. "Pengaruh Kualitas Pelayanan Dan Lokasi Terhadap Keputusan Pembelian Dengan Visual Merchandising Sebagai Variabel Moderating (Studi Pada Mini Market Alfamart Di Kota Semarang)". Jurnal Fokus Ekonomi. Vol. 9. No. 1. Hal. 65-80. STIE Pelita Nusantara. Semarang. 